\title{
WUJUD PRAGMATIK KESANTUNAN IMPERATIF DALAM PROSES PEMBELAJARAN SISWA KELAS VIII SMP NEGERI 1 PONDOK KELAPA BENGKULU TENGAH
}

\author{
Retno Esti Nugraheni \\ resti041@gmail.com \\ Guru SMP Negeri 1 Pondok Kelapa Bengkulu Tengah
}

\begin{abstract}
Abstrak
Penelitian ini bertujuan untuk mendeskripsikan wujud pragmatik kesantunan imperatif dalam proses pembelajaran siswa kelas VIII SMP Negeri 1 Pondok Kelapa Bengkulu Tengah. Penelitian ini merupakan penelitian deksripsi kualitatif. Data dalam penelitian ini yaitu data verbal tersebut berupa tuturan dalam interaksi siswa dengan siswa, maupun siswa dengan guru di lingkungan kelas VIII SMP Negeri Pondok Kelapa Bengkulu Tengah. Pengumpulan data dengan cara observasi, rekamanan, dan pencatatan. Penganalisisan data dilakukan dengan beberapa tahapan yaitu dengan (1) transkripsi data, (2) pengkodean data, (3) pengidentifikasian data, (4) pengklasifikasian data, (5) interpretasi data, dan (6) tahap penyimpulan. Berdasarkan hasil penelitian mengenai wujud pragmatik kesantunan imperatif dalam proses pembelajaran siswa kelas VIII SMP Negeri 1 Pondok Kelapa Bengkulu Tengah terdiri dari sembilan tuturan yang mengandung makna pragmatik imperatif yang terdiri dari perintah, permintaan, desakan, persilaan, ajakan, permintaan izin, mengizinkan, larangan, dan ngelulu. Makna mperatif tersebut ditandai dengan wujud kesantunan dalam bentuk tuturan imperatif perintah menggunakan partikel -lah, -kan, tuturan mperatif permintaan menggunakan kalimat tolong, tuturan imperatif desakan menggunakan tuturan yang dituturkan secara berulang-ulang, tuturan imperatif persilaan bentuk tuturannya adalah silakan, ya, tuturan imperatif ajakan menggunakan kalimat ayo!, tuturan imperatif mengizinkan bentuk tuturannya adalah baiklah, iya., tuturan imperatif larangan menggunakan kalimat jangan, dan tuturan imperatif ngelulu bentuk tuturannya adalah mengucapkan kata teruslah namun sebenarnya makna yang dimaksud yaitu untuk berhenti.
\end{abstract}

Kata Kunci: Pragmatik, Kesantunan, Imperatif

\section{PENDAHULUAN}

Kesantunan di dalam tuturan imperatif sangat penting dilakukan oleh penutur untuk menghargai mitra tutur. Secara linguistik, kesantunan dalam pemakaian tuturan imperatif bahasa Indonesia sangat ditentukan oleh muncul atau tidak munculnya ungkapanungkapan penanda kesantunan. Untuk menilai santun tidaknya sebuah tuturan dapat digunakan skala ketidak- langsungan Leech dan muncul atau tidaknya ungkapan penanda kesantunan seperti yang dikemukakan oleh Rahardi. Skala ketidaklangsungan Leech (dikutip oleh Rahardi, 2005: 67) menunjuk kepada peringkat langsung atau tidaknya sebuah tuturan. Semakin suatu tuturan bersifat langsung, maka semakin dianggap tidak santunlah tuturan itu dan semakin suatu tuturan bersifat tidak langsung maka semakin dianggap 
santunlah tuturan itu. Kesantunan dalam tuturan imperatif sangat ditentukan oleh muncul tidaknya ungkapan-ungkapan penanda kesantun-an seperti Maaf, tolong, coba, mohon, dan sebagainya, namun dalam kenyataannya tidak semua penutur menggunakan penanda kesantunan tersebut dalam tuturan imperatifnya kepada mitra tutur.

Dalam proses belajar mengajar di sekolah, bahasa Indonesia merupakan bahasa pengantar yang digunakan oleh guru untuk menyampaikan materi, tugas atau memberikan reaksi terhadap kontribusi yang dilakukan oleh siswa. Salah satu bentuk tuturan yang dimanfaatkan oleh para guru untuk pengaturan serta pemberian tanggapan terhadap tindakan dari siswa adalah bentuk tuturan yang mengandung makna atau maksud pragmatik imperatif dalam bahasa Indonesia. Pemanfaatan itu berkisar antara imperatif yang memiliki kadar tuturan paling lembut sampai imperatif yang memiliki kadar tuturan yang keras.

Selama proses belajar mengajar sedang berlangsung tidak setiap saat guru menggunakan bentuk imperatif langsung. Adakalanya mereka menggunakan bentuk imperatif tidak langsung, yaitu kontruksi deklaratif dan interogatif. Kedua kontruksi ini digunakan sebagai bentuk penghalusan. Penafsiran terhadap makna atau maksud penggunaan bentuk imperatif tidak langsung harus memperhatikan konteks yang melengkapi tuturan itu. Melihat gaya tuturan dalam proses kegiatan belajar mengajar di sekolah yang kompleks dan perlunya konteks situasi dalam memahami tuturan, maka perlu ditinjau secara pragmatik. Pragmatik mengkaji maksud penutur dalam menuturkan sebuah satuan lingual tertentu pada sebuah bahasa.

Rahardi (2005: 93) menyebutkan bahwa wujud imperatif pragmatik adalah realisasi maksud imperatif dalam bahasa Indonesia apabila dikaitkan dengan konteks situasi tutur yang melatarbelakanginya. Artinya, setiap tuturan imperatif penutur memiliki rnaksud imperatif berupa strategi dalam tuturan imperatif.

Penulis memilih analisis kesantunan imperatif dalam berbahasa pada tuturan guru dan siswa berdasarkan pertimbangan bahwa, ragam bahasa yang tidak santun sering menjadi instrumen komunikasi, baik antara guru dengan siswa maupun siswa dengan siswa lainnya pada saat kegiatan belajar-mengajar berlangsung. Penelitian terhadap penggunaan bahasa guru dan siswa merupakan hal yang penting. Ini dimaksudkan untuk memperoleh gambaran terhadap interaksi kebahasaan yang berlangsung dalam proses belajarmengajar di kelas. Oleh karena penulis tertarik untuk melakukan penelitian yang berjudul "Wujud Pragmatik Kesantunan Imperatif dalam Proses Pembelajaran Siswa Kelas VIII SMP Negeri 1 Pondok Kelapa Bengkulu Tengah".

Menurut Brown dan Levinson (1987), kesantunan berbahasa ini dimaknai sebagai usaha penutur untuk menjaga harga diri, atau wajah, pembicara maupun pendengar. Prinsip kesantunan dalam berkomunikasi merupakan sesuatu yang universal, meskipun setiap budaya dan kelompok masyarakat memiliki ukuran kesantunan dan ungkapan kesantunan yang beraneka ragam. ( dikutip oleh Markhamah, 2009: 153) 
Teori kesantunan berbahasa munurut Brown dan Levinson (dalam Jaworski, 2006: 131) yang mengatakan bahwa "some universal in language usage of society have "face". The public self-image that every member want to claim for himself, consisting in two related aspect, it is negative face and positive face." Beberapa universal dalam penggunaan bahasa masyarakat memiliki "wajah". Masyarakat citra diri yang ingin setiap anggota untuk mengklaim untuk dirinya sendiri, yang terdiri dalam dua aspek yang terkait, itu adalah wajah negatif dan wajah positif.

Pranowo (2009: 6), agar pemakaian bahasa terasa semakin santun, penutur dapat berbahasa dengan menggunakan bentuk-bentuk tertentu yang dapat dirasakan sebagai bahasa santun, seperti:

1) Menggunakan tuturan tidak langsung biasanya terasa lebih santun jika dibandingkan dengan tuturan yang diungkapkan secara langsung.

2) Pemakaian bahasa dengan kata-kata kias terasa lebih santun dibandingkan dengan pemakaian bahasa dengan kata-kata lugas.

3) Ungkapan memakai gaya bahasa penghalus terasa lebih santun dibandingkan dengan ungkapan biasa.

4) Tuturan yang dikatakan berbeda dengan yang dimaksudkan biasanya tuturan lebih santun.

5) Tuturan yang dikatakan secara implisit biasanya lebih santun dibandingkan dengan tuturan yang dikatakan secara eksplisit.

Menurut Rahardi (2005: 125), ungkapan-ungkapan penanda kesantunan menjadi sebagai ciri-ciri kesantunan. Kesantunan berbahasa dalam pemakaian tuuturan imperatif misalnya ditentukan oleh muncul atau tidak munculnya ungkapan-ungkapan penanda kesantunan seperti tolong, mohon, silakan, mari, ayo, biar, coba, harap, hendaknya, sudi kiranya, dan sudi apalah kiranya. Penanda-penanda kesantunan ini menentukan tinggirendahnya peringkat kesantunan berbahasa seseorang ketika berkomunikasi.

Searle (1975) dikutip oleh Chaer (2010: 29) membagi tindak tutur atas lima kategori, yaitu tindak tutur:

1) Representatif, yaitu tindak tutur yang mengikat penuturnya kepada kebenaran atas apa yang dikatakannya.

2) Direktif, yaitu tindak tutur yang dilakukan penuturnya dengan maksud agar lawan tutur melakukan tindakan yang disebutkan dalam tuturan itu.

3) Ekspresif, yaitu tindak tutur yang dilakukan dengan maksud agar tuturannya diartikan sebagai evaluasi mengenai hal yang disebutkan di dalam tuturan itu.

4) Komisif, yaitu tindak tutur yang mengikat penuturnya untuk melaksanakan apa yang disebutkan di dalam tuturannya.

5) Deklarasi, yaitu tindak tutur yang dilakukan si penutur dengan maksud untuk menciptakan hal (status, keadaan, dan sebagainya) yang baru.

Tindak tutur direktif yang dirumuskan Bach dan Harnish (1979) dikutip oleh Wardhana, Dian Eka Chandra (2006: 39) diklasifikasikan menjadi lima. Kelima macam tindak tutur direktif yang dimaksudkan adalah (1) Permintaan, yang mencakup meminta, memohon, mengajak, mendorong, 
mengundang, dan menekan., (2) Pertanyaan, yang mencakup bertanya, inkuiri, dan interogasi., (3) Persyaratan yang mencakup mensyaratkan, memerintah, mengomando, menuntut, mendikte, mengarahkan, mengintruksikan, dan mengatur., (4) Larangan yang mencakup melarang dan membatasi., (5) Persilaan, yang mencakup memberi izin, membolehkan, mengabulkan, melepaskan, memperkenalkan, memberi wewenang dan menganugerahi., dam (6) Nasihat yang mencakup menasehati, memperingatkan, mengusulkan, membimbing, menyarankan, dan mendorong.

Dell Hymes (1978) dalam Pranowo (2009: 100) menyatakan bahwa ketika seseorang berkomunikasi hendaknya memerhatikan beberapa komponen tutur yang diakronimkan dengan istilah SPEAKING, yaitu sebagai berikut:

1) Setting and Scene, (latar). Setting berkenaan dengan waktu dan tempat tutur berlangsung, sedangkan scene mengacu pada situasi tempat dan waktu, atau situasi psikologis pembicaraan.

2) Participants, (peserta). Adalah pihakpihak yang terlibat dalam penuturan, bisa pembicara dan pendengar, penyapa dan pesapa, atau pengirim pesan dan penerima pesan.

3) Ends, (tujuan komunikasi). Mengacu pada tujuan yang ingin dicapai dalam berkomunikasi.

4) Act Sequences, (pesan yang ingin disampaikan). Mengacu pada bentuk dan pesan yang ingin disampaikan.

5) Key, (kunci). Mengacu pada pelaksanaan percakapan.

6) Instrumentalities, (sarana). Mengacu pada jalur bahasa yang digunakan seperti jalur lisan, tertulis, melalui telegraf atau telepon.

7) Norms, (norma). Pranata sosial kemasyarakatan yang mengacu pada norma perilaku partisipan dalam berkomunikasi.

8) Genres, (ragam). Mengacu pada ragam bahasa yang digunakan, misalnya rgaam formal, ragam santai, dan sebagainya.

Rahardi (2005: 79) menuliskan bahwa kalimat imperatif mengandung maksud memerintah atau meminta agar mitra tutur melakukan suatu sebagaimana diinginkan si penutur. kalimat imperatif dapat diklasifikasikan secara formal menjadi lima macam, yakni:

1) Kalimat imperatif biasa

2) Kalimat imperatif permintaan

3) Kalimat imperatif pemberian izin

4) Kalimat imperatif ajakan

5) Kalimat imperatif suruhan

Linguistik sebagai ilmu bahasa memiliki bermacam-macam cabang. Salah satu cabangnya adalah pragmatik. Pragmatik adalah cabang ilmu bahasa yang mempelajari struktutur bahasa secara eksternal, yakni bagaimana satuan kebahasaan itu digunakan di dalam komunikasi (Putu Wijana, 1996: 1)

Pragmatik adalah studi bahasa yang mendasarkan pijakan analisisnya pada konteks (Rahardi, 2005: 50). Selanjutnya Yule (1996: 3 ) mengatakan bahwa "Pragmatics is the study of contextual meaning" "pragmatik adalah studi tentang makna kontekstual".

Rahardi (2005: 93) memaparkan bahwa yang dimaksud dengan wujud pragmatik adalah realisasi maksud imperatif dalam bahasa Indonesia apabila dikaitkan dengan konteks situasi tutur yang melatarbelakanginya. Makna 
imperatif yang demikian itu sangat ditentukan oleh konteksnya. Konteks yang dimaksud dapat bersifat ekstralinguistik dan dapat pula bersifat intralinguistik.

Pengelompokan wujud pragmatik imperatif dalam penelitian Rahardi (2005: 93-116) mengklasifikasikan wujud makna pragmatik menjadi beberapa jenis makna pragmatik imperatif. Berikut adalah macam-macam wujud makna pragmatik imperatif menurut Rahardi (2005: 93) adalah tuturan yang mengandung makna pragmatik imperatif perintah, tuturan yang mengandung makna pragmatik imperatif permintaan, tuturan yang mengandung makna permohonan, tuturan yang mengandung makna pragmatik imperatif desakan, tuturan yang mengandung makna pragmatik imperatif imbauan, tuturan yang mengandung makna pragmatik imperatif persilaan, tuturan yang mengandung makna pragmatik imperatif ajakan, tuturan yang mengandung makna pragmatik imperatif permintaan izin, tuturan yang mengandung makna pragmatik imperatif mengizinkan, tuturan yang mengandung makna pragmatik imperatif larangan, tuturan yang mengandung makna pragmatik imperatif pemberian ucapan selamat, dan tuturan yang mengandung makna pragmatik imperatif ngelulu.

\section{METODE PENELITIAN}

Metode yang peneliti gunakan dalam penelitian ini adalah dengan menggunakan metode penelitian deskriptif. Lokasi penelitian ini dilakukan di SMP Negeri 1 Pondok Kelapa Kabupaten Bengkulu Tengah Provinsi Bengkulu. Waktu penelitian dimulai sejak
9 September 2015 sampai 9 November 2015.

Data dalam penelitian ini berupa data verbal. Data verbal tersebut berupa tuturan dalam interaksi siswa dengan siswa, maupun siswa dengan guru di lingkungan kelas VIII SMP Negeri Pondok Kelapa. Sumber data dalam penelitian ini adalah interaksi antara guru dan seluruh siswa yang berada di kelas VIII SMP Negeri 1 Pondok kelapa.

Teknik pengumpulan data yang digunakan dalam penelitian ini adalah observasi dan rekaman. Penganalisisan data dalam penelititan ini dilakukan melalui tahapan-tahapan 1) mentranskripkan data, 2) pengkodean data, 3) pengidentifikasian data, 4) pengklasifikasian data, 5) interpretasi data, dan 6) penyimpulan.

Teknik yang digunakan untuk memeriksa keabsahan data dalam penelitian ini adalah dengan menggunakan teknik triangulasi.

\section{HASIL DAN PEMBAHASAN}

Tuturan wujud pragmatik kesantunan imperatif dalam proses pembelajaran siswa kelas VIII SMP Negeri Pondok Kelapa Bengkulu Tengah ditemukan 56 tuturan. Tuturan mencakup dalam sembilan tuturan, yaitu (1) Tuturan yang mengandung makna pragmatik imperatif perintah, (2) Tuturan yang mengandung makna pragmatik imperatif permintaan, (3) Tuturan yang mengandung makna pragmatik imperatif desakan, (4) Tuturan yang mengandung makna pragmatik imperatif persilaan, (5) tuturan yang mengandung makna pragmatik imperatif ajakan, (6) Tuturan yang mengandung makna pragmatik imperatif permintaan izin, (7) Tuturan 
yang mengandung makna pragmatik imperatif mengizinkan, (8) Tuturan yang mengandung makna pragmatik imperatif larangan, (9) Tuturan yang mengandung makna pragmatik imperatif ngelulu. Sedangkan terdapat 3 tuturan pragmatik imperatif yang tidak ditemukan.Tuturan tersebut meliputi (1) tuturan yang mengandung makna pragmatik imperatif permohonan, (2) Tuturan yang mengandung makna pragmatik imperatif imbauan dan (3) Tuturan yang mengandung makna pragmatik imperatif pemberian ucapan selamat tidak ditemukan dalam penelitian ini.

Berikut hasil penelitian dalam bentuk tabel.

Tabel. 1 Hasil Penelitian Wujud Pragmatik Kesantunan Imperatif dalam Proses Pembelajaran Siswa Kelas VIII SMP Negeri 1 Pondok Kelapa Bengkulu Tengah

\begin{tabular}{|c|c|c|c|c|c|c|}
\hline \multirow{2}{*}{ No } & \multirow{2}{*}{$\begin{array}{l}\text { Wujud Pragmatik Kesantunan } \\
\text { Imperatif }\end{array}$} & \multicolumn{4}{|c|}{ Data Tuturan } & \multirow{2}{*}{$\begin{array}{l}\text { Jumlah } \\
\text { Tuturan }\end{array}$} \\
\hline & & VIII.A $_{A}$ & VIII.B $_{\text {B }}$ & VIII. $_{. c}$ & VIII.E $_{\text {E }}$ & \\
\hline 1 & $\begin{array}{l}\text { Tuturan yang mengandung makna } \\
\text { pragmatik imperatif perintah }\end{array}$ & - & 3 & 3 & 7 & 13 tuturan \\
\hline 2 & $\begin{array}{l}\text { Tuturan yang mengandung makna } \\
\text { pragmatik imperatif permintaan }\end{array}$ & - & 1 & 3 & 1 & 5 tuturan \\
\hline 3 & $\begin{array}{l}\text { Tuturan yang mengandung makna } \\
\text { pragmatik imperatif desakan }\end{array}$ & 1 & 1 & 2 & 1 & 5 tuturan \\
\hline 4 & $\begin{array}{l}\text { Tuturan yang mengandung makna } \\
\text { pragmatik imperatif persilaan }\end{array}$ & 1 & 1 & 1 & 4 & 7 tuturan \\
\hline 5 & $\begin{array}{l}\text { Tuturan yang mengandung makna } \\
\text { pragmatik imperatif ajakan }\end{array}$ & - & 1 & 3 & - & 4 tuturan \\
\hline 6 & $\begin{array}{l}\text { Tuturan yang mengandung makna } \\
\text { pragmatik imperatif permintaan } \\
\text { izin }\end{array}$ & - & 2 & 3 & - & 5 tuturan \\
\hline 7 & $\begin{array}{l}\text { Tuturan yang mengandung makna } \\
\text { pragmatik imperatif mengizinkan }\end{array}$ & - & - & 3 & - & 3 tuturan \\
\hline 8 & $\begin{array}{l}\text { Tuturan yang mengandung makna } \\
\text { pragmatik imperatif larangan }\end{array}$ & 1 & 2 & 4 & 4 & 11 tuturan \\
\hline 9 & $\begin{array}{l}\text { Tuturan yang mengandung makna } \\
\text { pragmatik imperatif ngelulu }\end{array}$ & - & 2 & 1 & - & 3 tuturan \\
\hline \multicolumn{2}{|c|}{ Jumlah } & 3 & 13 & 23 & 17 & 56 \\
\hline
\end{tabular}

Data yang ditemukan oleh penulis yang mengandung makna pragmatik kesantunan imperatif perintah dapat dilihat pada data 20/VIII.E/OnpRek/14092015/KI yaitu tuturan yang diucapkan oleh siswa dengan siswa sebagai berikut:

\section{Data 20}

\section{0/VIII.E/OnpRek/14092015/KI}

Pelaku : Siswa - Siswa

Siswa $_{1}$ : Perempuan, 14 thn sebagai $M_{1}$ Siswa $_{2}$ : Laki-laki, 14 thn sebagai $\mathrm{M}_{2}$ Waktu : Siang hari, Senin, 14 September 2015, pukul 12.07 WIB

Setting: Di dalam kelas VIII.E saat mahasiswa dan siswa mulai 
melaksanakan proses pembelajaran Fisika

$M_{1} \quad$ : Woy iko bolong belum ? 'Woy, ini bolong belum ?'

$\mathrm{M}_{2}$ : Woy jadilah kalu, berentilah. Segitu bae.'Woy mungkin sudah cukup seperti itu.Seperti itu saja.'

Konteks

Siswa sedang mengerjakan tugas kelompok di dalam kelompoknya masing-masing.Siswa kemudian melakukan percakapan dengan salah satu siswa yang berada disampingnya.

Percakapan antara guru dan siswa seperti yang tertulis di data 20/VIII.E/OnpRek/14092015/KI

merupakan tuturan yang mengandung makna pragmatik imperatif perintah. Imperatif perintah tersebut muncul ketika seorang siswa yang bertanya kepada siswa yang berada disampingnya mengenai seberapa dalam membuat lobang pada alat peraga yang akan mereka gunakan. Siswa tersebut kemudian menjawab dengan perintah untuk mengehentikan pembuatan lobang pada alat peraga. $\mathrm{Hal}$ ini dikarenakan bagi siswa tersebut alat peraga tersebut sudah cukup sesuai dengan kebutuhan untuk pembelajaran.

Kalimat Woy jadilah kalu, berentilah.Segitu bae mengandung makna imperatif perintah. Penggunaan kalimat berhentilah merupakan salah satu kata kerja yang dituturkan oleh penutur. Penggunaan kata kerja tersebut bermaksud bahwa lawan tutur untuk mengerjakan apa yang diucapkan oleh penutur. Penggunaan kalimat berentilah menggunakan partikel -lah sebagai wujud kesantunan dengan menggunakan kalimat yang mengandung makna perintah untuk berhenti.Tuturan data 20/VIII.E/OnpRek/14092015/KI ini penutur bukan hanya memerintahkan kepada mitra tutur, namun juga memberikan solusi terhadap yang diucapkannya.Penggunaan partikel -lah merupakan kalimat yang digunakan dalam wujud kesantunan sehingga lawan tuutr mengerjakan berdasarkan yang dituturkan oleh penutur.Berdasarkan perintah tersebut, maka tuturan tersebut merupakan tuturan yang mengandung makna pragmatik kesantunan imperatif perintah.

Wujud dan penggunaan kesantunan berbahasa menggunakan tuturan yang mengandung makna pragmatik imperatif perintah muncul apabila terdapat ungkapan-ungkapan penanda kesantunan dalam berbahasa. Kesantunan berbahasa dalam pemakaian tuturan imperatif misalnya ditentukan oleh munculnya ungkapan-ungkapan penanda kesantunan misalnya partikel lah, -kanseperti kerjakanlah, benarkan. Penggunaan intonasi yang lembut terdengar lebih santun pada saat mengucapkan tuturan. Faktor situasi yang menyebabkan ujaran yang dikeluarkan berupa ujaran yang berintonasi sedikit tinggi, misalnya keadaan gaduh yang terjadi di kelas pada saat proses belajar berlangsung.

Wujud dan penggunaan kesantunan berbahasa menggunakan tuturan yang mengandung makna pragmatik imperatif permintaan muncul apabila terdapat ungkapan-ungkapan penanda kesantunan berbahasa. Kesantunan berbahasa dalam pemakaian tuturan imperatif misalnya ditentukan oleh munculnya ungkapan-ungkapan penanda kesantunan misalnya tolong dan mohon. Penggunaan intonasi yang lembut terdengar dan terdapat juga tuturan yang diucapkan dengan sedikit 
memelas terdengar lebih santun pada saat mengucapkan tuturan. Penggunaan tuturan yang diucapkan secara langsung juga banyak ditemukan oleh peneliti dalam penelitian ini. Namun berdasarkan konteks setiap ujaran maka peneliti dapat menyimpulkan bahwa tuturan tersebut merupakan tuturan yang mengandung makna pragmatik imperatif permintaan.

Wujud dan penggunaan kesantunan berbahasa menggunakan tuturan yang mengandung makna pragmatik imperatif desakan muncul apabila terdapat ungkapan-ungkapan penanda kesantunan dalam berbahasa. Kesantunan berbahasa dalam pemakaian tuturan imperatif misalnya ditentukan oleh munculnya ungkapan-ungkapan penanda kesantunan misalnya ayo. Tuturan yang diucapkan seringkali dilakukan secara berulang-ulang. Penggunaan bahasa yang dengan intonasi rendah dan diucapkan berulangulang akan terasa lebih santun.

$$
\text { Wujud dan penggunaan }
$$

kesantunan berbahasa menggunakan tuturan yang mengandung makna pragmatik imperatif persilaan muncul apabila terdapat ungkapan-ungkapan penanda kesantunan berbahasa. Kesantunan berbahasa dalam pemakaian tuturan imperatif misalnya ditentukan oleh munculnya ungkapan-ungkapan penanda kesantunan misalnya silakan dan dipersilakan. Kedua macam penanda kesantunan ini masing-masing memiliki makna persilaan. Makna pragmatik tuturan imperatif persilaan pada komunkasi dalam proses pembelajaran dapat ditemukan dengan penggunaan tuturan yang bersifat langsung misalnya pada data 28/VIII.E/OnpRek/14092015/KI yaitu Siapa yang mau bertanya?
Wujud dan penggunaan kesantunan berbahasa menggunakan tuturan yang mengandung makna pragmatik imperatif ajakan muncul apabila terdapat ungkapan-ungkapan penanda kesantunan berbahasa. Kesantunan berbahasa dalam pemakaian tuturan imperatif misalnya ditentukan oleh munculnya ungkapan-ungkapan penanda kesantunan misalnya ayo dan mari. Kedua macam penanda kesantunan ini masing-masing memiliki makna ajakan. Penggunaan intonasi yang lembut terdengar terdengar lebih santun pada saat mengucapkan tuturan. Secara pragmatik, maksud ajakan ternyata tidak selalu dwujudkan dengan tuturan-turan yang berbentuk imperatif. Penggunaan tuturan yang diucapkan secara langsung dalam mengungkapkan kalimat imperatif ajakan juga banyak ditemukan oleh peneliti dalam penelitian ini. Namun berdasarkan konteks setiap ujaran maka peneliti dapat menyimpulkan bahwa tuturan tersebut merupakan tuturan yang mengandung makna pragmatik imperatif ajakan.

Wujud dan penggunaan kesantunan berbahasa menggunakan tuturan yang mengandung makna pragmatik imperatif permintaan izin muncul apabila terdapat ungkapanungkapan penanda kesantunan berbahasa. Kesantunan berbahasa dalam pemakaian tuturan imperatif misalnya ditentukan oleh munculnya ungkapanungkapan penanda kesantunan misalnya boleh. Penanda kesantunan ini memiliki makna permintaan izin. Penggunaan intonasi yang lembut terdengar terdengar lebih santun pada saat mengucapkan tuturan.Secara pragmatik, maksud permintaan izin ternyata tidak selalu dwujudkan dengan tuturan- 
tuturan yang berbentuk imperatif. Penggunaan tuturan yang diucapkan secara langsung dalam mengungkapkan kalimat imperatif permintaan izin juga banyak ditemukan oleh peneliti dalam penelitian ini. Namun berdasarkan konteks setiap ujaran maka peneliti dapat menyimpulkan bahwa tuturan tersebut merupakan tuturan yang mengandung makna pragmatik imperatif ajakan.Hal ini dapat dilihat pada data 29/VIII.E/OnpRek/14092015/KI. Tuturan yang diucapkan yaitu Pak. (sambil mengacungkan jari.'Pak. (sambil mengacungkan jari)' yangbermaksud bahwa meminta izin untuk bertanya.

$$
\text { Wujud dan penggunaan }
$$

kesantunan berbahasa menggunakan tuturan yang mengandung makna pragmatik imperatif mengizinkan muncul apabila terdapat ungkapan-ungkapan penanda kesantunan berbahasa yang diucapkan apabila ada seorang penutur yang mengucapkan kalimat imperatif permintaan izin. Kesantunan berbahasa dalam pemakaian tuturan imperatif misalnya ditentukan oleh munculnya ungkapan-ungkapan penanda kesantunan misalnya ya, silakan, baiklah. Ketiga penanda kesantunan ini memiliki makna mengizinkan. Penggunaan intonasi yang lembut terdengar terdengar lebih santun pada saat mengucapkan tuturan.Namun peneliti juga mendapatkan pengucapan tuturan imperatif yang diucapkan dengan intonasi tegas. Hal ini disebabkan karena faktor usia dan tingkat pendidikan penutur. Penutur merupakan seorang guru dalam proses pembelajaran berlangsung. Secara pragmatik, maksud mengizinkan ternyata tidak selalu dwujudkan dengan tuturan-turan yang berbentuk imperatif. Penggunaan tuturan yang diucapkan secara langsung dalam mengungkapkan kalimat imperatif mengzinkan juga banyak ditemukan oleh peneliti dalam penelitian ini. Namun berdasarkan konteks setiap ujaran maka peneliti dapat menyimpulkan bahwa tuturan tersebut merupakan tuturan yang mengandung makna pragmatik imperatif ajakan. Hal ini dapat dilihat pada data 39/VIII.c/OnpRek/21092015/ KI. Tuturan yang diucapkan yaitu cuma 5 menit bae 'hanya 5 menit saja.' Yang bermaksud penutur (guru) mengizinkan siswanya namun diberikan tenggang waktu hanya 5 menit saja.

Wujud dan penggunaan kesantunan berbahasa menggunakan tuturan yang mengandung makna pragmatik imperatif larangan muncul apabila terdapat ungkapan-ungkapan penanda kesantunan berbahasa yang diucapkan apabila ada seorang penutur yang mengucapkan kalimat imperatif larangan.Kesantunan berbahasa dalam pemakaian tuturan imperatif misalnya ditentukan oleh munculnya ungkapanungkapan penanda kesantunan misalnya jangan. Penanda kesantunan ini memiliki makna mengizinkan. Penggunaan intonasi yang lembut terdengar lebih santun pada saat mengucapkan tuturan. Imperatif yang bermakna larangan dapat diwujudkan secara pragmatk dalam proses pembelajaran tersebut. Wujud pragmatik itu ternyata dapat berupa tuturan yang bermacam-macam dan tidak selalu berbentuk tuturan imperatif. Namun berdasarkan konteks setiap ujaran maka peneliti dapat menyimpulkan bahwa tuturan tersebut merupakan tuturan yang mengandung makna pragmatik imperatif larangan.Hal ini dapat dilihat pada data 32/VIII.A/OnpRek/17092015/KI. Tuturan 
yang diucapkan yaitu Arenza ! (membentak) 'Arenza! (membentak) yang bermaksud penutur (guru) melarang siswanya yang bernama Arenza.

Wujud dan penggunaan kesantunan berbahasa menggunakan tuturan yang mengandung makna pragmatik imperatif ngelulu muncul apabila terdapat ungkapan-ungkapan penanda kesantunan berbahasa. Kesantunan berbahasa dalam pemakaian tuturan imperatif misalnya ditentukan oleh munculnya ungkapan-ungkapan penanda kesantunan yang bermakna menyuruh atau mengiyakan namun sebenarnya yang dimaksud adalah melarang ataupun menolaknya. Penggunaan intonasi yang lembut terdengar dan terdapat juga tuturan yang diucapkan terdengar lebih santun pada saat mengucapkan tuturan. Hal ini dapat dilihat pada data 04/VIII. Rek/09092015/KI yang berupa tuturan lyo .dak papo dapet paragraf yang banyak Aku ni. Pena ni teruslah macet cak ini. Dak tau apo kalau orang ni kesal. Penutur mengucapkan kata teruslah namun sebenarnya makna yang dimaksud yaitu untuk berhenti

\section{SIMPULAN}

Tuturan yang mengandung makna pragmatik imperatif perintah merupakan tuturan yang diucapkan oleh seseorang untuk melakukan suatu tindakan. Salah satu bentuk tuturannya adalah kerjokelah. Partikel -lah, -kan menandakan suatu perintah mengerjakan sesuatu, imperatif permintaan menggunakan kalimat tolong. Penggunaan tuturan yang dituturkan secara berulang-ulang termasuk dalam imperatif perintah.
Salah satu bentuk tuturan imperatif persilaan adalah silakan, imperatif ajakan merupakan bentuk tuturannya adalah ayo !, imperatif permintaan izin bentuk tuturannya adalah permisi, imperatif mengizinkan bentuk tuturannya adalah baiklah, iya., imperatif larangan bentuk tuturannya adalah jangan, imperatif ngelulu bentuk tuturannya adalah lyo . dak papo dapet paragraf yang banyak Aku ni. Pena ni teruslah macet cak ini. Dak tau apo kalau orang ni kesal. Penutur mengucapkan kata teruslah namun sebenarnya makna yang dimaksud yaitu untuk berhenti

Berdasarkan simpulan di atas, maka disarankan: 1) Bagi guru diharapkan untuk tetap mempertahankan menggunakan bahasa yang secara tidak langsung seperti pada saat guru mengajar. Hal ini perlahan dapat membantu siswa untuk meniru guru tersebut dalam penggunaan bahasa yang digunakan dari setiap tuturannya. 2) Bagi para peneliti, mudah-mudahan penelitian ini dapat mendorong penelitian lain untuk melanjutkan dengan mencari hal-hal yang belum terungkap di dalam penelitian yang dilakukan pada penelitian sebelumnya. 3) Keterbatasan penelitian ini bahwa penelitian berupa alat penelitian yang memungkinkan misalnya menggunakan audio visual pada setiap siswa. Penulis juga menyadari bahwa data penelitian masih belum lengkap dan masih terbuka untuk diadakan penelitian lebih lanjut mengenai kesantunan imperatif ataupun persoalan lain yang dapat diungkap dalam kaitannya dengan kesantunan berbahasa. 


\section{DAFTAR PUSTAKA}

Arikunto, Suharsini. 2006. Prosedur Penelitian: Suatu Pendekatan Praktik. Jakarta: PT Rineka Cipta.

Chaer, Abdul dan Leonie Agustina. 2010. Sosiolinguistik. Jakarta: Rinneka Cipta.

Chaer, Abdul. 2010. Kesantunan Berbahasa. Jakarta: Rinneka Cipta.

Djajasudarma, Fatimah. 2006. Metode Linguistik: Ancangan Metode Penelitian dan Kajian. Bandung: PT Refika Aditama.

Ibrahim, A. S. 1990. Sosiolinguistik: Kajian, Tujuan, Pendekatan dan Problem. Surabaya: Usaha Nasional.

Jaworski, Adam dan Nikolas Coupland. 2006. The Discourse Reader. New York:

Markhamah, dkk. 2009. Analisis Kesalahan dan Kesantunan Berbahasa. Surakarta: Universitas Muhammadiyah Surakarta.

Pranowo. 2009. Berbahasa Secara Santun. Yogyakarta: Pustaka Belajar.
Rahardi, R.Kunjana. 2005. Pragmatik Kesantunan Imperatif Bahasa Indonesia. Jakarta: Erlangga.

Routledge.

Susetyo, 2009. Menulis Akademik. Bengkulu: FKIP UNIB.

Syamsuddin, dan Damaianti. 2009. Metode Penelitian Pendidikan Bahasa. Bandung: Refika Aditama.

Wahyuni, Sari. 2014. Skripsi: Kesantunan Berbahasa Siswa di Lingkungan SMA Negeri 3 Kota Bengkulu. Universitas Bengkulu.

Wardhana, Dian Eka Chandra. 2006. Representasi Tindak Tutur Direktif Penutur Jawa Pendatang dalam Komunikasi Lisan Masyarakat Multietnik di Bengkulu. Disertasi tidak diterbitkan. Malang: Universitas Malang.

Wijana, I Dewa Putu. 1996. Dasar-dasar Pragmatik. Yogyakarta: Andi Offset. 